\title{
Morbidity Due to Obesity, Hypertension and Diabetes II Attributable to Non-Breastfeeding and Low Birth Weight during the 1000 Days of Life: Estimation of the Population Attributable Fraction
}

\author{
Andrea Ramírez¹, Oscar Bernal1, Jesús Rodríguez², José David Pinzón³ \\ ${ }^{1}$ Escuela de Gobierno Alberto Lleras Camargo, Universidad de los Andes, Bogotá, Colombia \\ ${ }^{2}$ Facultad de Ciencias Económicas y Administrativas, Pontificia Universidad Javeriana, Bogotá, Colombia \\ ${ }^{3}$ Especialización en Diseño Urbano y Maestría en Territorio y Ciudad, Universidad Jorge Tadeo Lozano, \\ Bogotá, Colombia \\ Email: aravamd@gmail.com, obernal@uniandes.edu.co, rodriguez-j@javeriana.edu.co, \\ josed.pinzon@gmail.com
}

Received 10 February 2016; accepted 12 March 2016; published 15 March 2016

Copyright (C) 2016 by authors and Scientific Research Publishing Inc.

This work is licensed under the Creative Commons Attribution International License (CC BY). http://creativecommons.org/licenses/by/4.0/ (c) (7)

\section{Abstract}

Introduction: There is evidence that malnutrition during the first $\mathbf{1 0 0 0}$ days of life contributes to the development of chronic diseases in adulthood and therefore may produce a lasting impact on the health of the population. Colombia, like other middle-income countries suffers the double burden of malnutrition in pregnant women and children under 5 years. Also, chronic diseases have positioned within the leading causes of morbidity and mortality. Objective: The aim is to estimate the burden of disease of noncommunicable chronic diseases-NCD's (hypertension, obesity, diabetes mellitus II) in adults attributable to nutritional risk factors (no-breastfeeding and low birthweight) in the period of 1000 days in Colombia. Methods: The population attributable fraction and the number of NCD's (hypertension, diabetes mellitus II and obesity) cases due to the risk factors (low birthweight and no-breastfeeding) were estimated. Prevalences of NCD's and risk factors of interest were taken from national health surveys. Effect measures (odds ratios/relative risks) of the associations 1-low birthweight and hypertension, diabetes mellitus II and 2-no-breastfeeding and obesity were obtained after a systematic literature search. Results: It was estimated that not receiving breastfeeding in the 1000 days could contribute up to $29.9 \%$ of all cases of obesity, equivalent to about 4,009,779 cases across the country. Low birth weight could contribute up to $2.1 \%$ of cases of hypertension in men and to $4.0 \%$ of cases in women, equivalent 
to $\mathbf{1 0 3 . 7 6 9}$ cases across the country. In addition, low birth weight could contribute to $6.3 \%$ of diabetes mellitus II cases, which is equivalent to 23.857 cases in the country. Conclusion: In Colombia, risk factors during the first $\mathbf{1 0 0 0}$ days like not receiving breastfeeding and having low birth weight could contribute up to 4,113,549 cases of obesity, hypertension and diabetes mellitus II, with important implications for the health of the population and the Colombian health system.

\section{Keywords}

\section{Epidemiologic Measurements, Breastfeeding, Low Birth Weight, Chronic Disease, Public Health}

\section{Introduction}

Currently, the non-communicable disease (NCD's) pandemic is a public health priority [1]. It is known to affect both developed and developing countries, however most deaths occur in low and middle-income countries [1]. Well known preventable risk factors like tobacco and alcohol use, physical inactivity and unhealthy diet including high consumption of saturated fats and low consumption of fruits and vegetables can lead to NCD's while contributing to physiological changes like raised blood pressure, excess weight, high blood sugar and lipid levels [1]. In addition to the aforementioned, other risk factors like child malnutrition, nutritional deficiencies and inadequate breastfeeding are also within the top 10 risk factors for mortality [1].

In 2008, it was estimated that in low- and middle-income countries; cardiovascular disease was the leading cause of death and the third leading cause of disability life years lost. It is expected that in 2020 NCD's like cardiovascular disease, obesity and diabetes contribute with about $57 \%$ to the global burden of disease [2] [3].

Obesity has become a problem in areas where there is still undernutrition like Latin America, Asia and parts of Africa. It is known that in the last decade, the prevalence has doubled or tripled. Despite this, in many developing countries the approach remains towards the treatment of the opposite end of malnutrition (low height for age, anemia, micronutrient deficiencies and malnutrition) and not to prevent the end related with overweight and the resulting chronic diseases [4].

\subsection{Evidence on the Development of Chronic Noncommunicable Diseases during Pregnancy and First 2 Years of Life}

Nutrition plays a key role in the prevention and control of morbidity and mortality due to NCD's being one of its determinants. There is evidence that nutritional disturbances have important short- and long-term adverse effects. Cardiovascular disease, obesity and diabetes among others can be prevented with adequate nutrition during all life stages [5]-[11].

There is now evidence of the progress of the disease from risk factors such as poor eating habits and sedentary lifestyle during adulthood, and in the last decade compelling evidence about the contribution of some factors in the first days of life in the development of these diseases was published. Fetal and early postnatal life factors such as breastfeeding have been shown to decrease the risk of obesity, diabetes mellitus type 2, hypertension and dyslipidemia development in adulthood [5] [8].

It is also known that individuals living in countries that are in demographic and nutritional transition are at risk due to the combination of nutrient restriction in utero and exposure to a nutrient rich environment in early postnatal life, which may lead to an accelerated growth that produces adverse health consequences in the long term [11]. This phenomenon has been particularly studied in women in reproductive age and children under 5 years [12] [13]. In these age groups in addition to observing major inequities between rural and urban areas, the coexistence of malnutrition (predominantly low height for age), anemia, vitamin A deficiency, overweight and obesity [14] [15] is observed.

\subsection{The Importance of the First 1000 Days of Life}

A critical 1000-day period that includes pregnancy and the first 2 years of age has been characterized as a period of high nutrition demand and essential for the development and growth of the individual [5] [6]. 
Inadequate fetal nutrition given by nutritional restriction, poor nutritional status of the mother (overweight) and diseases such as gestational diabetes are major early life exposures that may cause anatomical, hormonal and physiological changes altering the short-term survival the fetus and increasing the likelihood of developing diseases in the long term [16] [17]. Also, in recent decades, epidemiological evidence has shown that some conditions in early life have an impact on growth patterns, body composition and the long-term risk of chronic noncommunicable diseases (NCD) [18]-[20].

The associations between low birth weight, diabetes mellitus type 2, excess weight, high blood pressure, and increased risk of cardiovascular disease and mortality were originally described in European countries in the 1950 [18]-[20]. These observations led to investigations in which it was shown that inadequate nutrition during fetal development may induce changes that would provide a biological advantage in utero, but would become harmful in extra uterine environments with exposure to excess energy and lack of physical activity such as observed today [21]-[25]. This paradigm describes how during early life (fetal life, infancy and early childhood), the environment induces changes that have long-term health impact and risk of disease is known today as the early origins of health and disease (DOHaD: Developmental Origins of Health and Disease) [25].

Therefore, the evidence of early life interventions that may have an impact on the development of chronic diseases in adult life are compelling [18]-[26] and highlight the importance of proper nutrition in this period to counteract the effects of the epidemic of NCD's. For example, during pregnancy maintaining an adequate nutritional status during pregnancy, receiving prenatal care, micronutrient supplementation and having a newborn with adequate birth weight have proven effective [15]. Also, receiving optimal breastfeeding, micronutrient supplementation, appropriate complementary feeding during the first 2 years of life prevent maternal and infant mortality [15] [26] [27].

\subsection{The Malnutrition Problem during the 1000 Day Period in Colombia}

Like other middle-income countries, Colombia suffers the double burden imposed by malnutrition. In relation to breastfeeding, and although there appears to be a very slow progress, the median duration of exclusive breastfeeding increased from 0.5 months in 1999 to 2.2 months in 2010. Also the total duration of breastfeeding median increased from 11.3 months in 1999 to 14.9 months in 2010, however both indicators are still below the 6 and 24 month international recommendation respectively [28].

Regarding the nutritional status, in the pregnant women group it was found that in 2010 only $42.9 \%$ had a normal body mass index, $16.2 \%$ were underweight, $24.8 \%$ were overweight and $9.8 \%$ obese [29], In newborns, the prevalence of low birth weight was $9.0 \%$ [30] and in children under 5 years overweight and obesity prevalence was of $20.2 \%$ and $5.2 \%$ respectively [28].

As for the micronutrient deficiencies, a high prevalence of anemia, iron and vitamin b12 deficiency were found in both pregnant women and children under 3. Specifically vitamin A and zinc were deficient in children under 3 [28].

\subsection{The Problem of NCD's in Colombia}

In Colombia, there has been an increasing prevalence of overweight and obesity in the population, associated with the development of chronic diseases like diabetes, cardiovascular disease and hypertension [31] [32]. According to the National Institute of Health, in 2013 it was estimated that cardiovascular disease was the leading cause of death in Colombia [33].

As in other countries in Latin America and the Caribbean, Colombia has one of the largest burden of disease from non-communicable diseases according to the 2009 Global Report of the WHO [1]. In the last of the burden of disease studies conducted in 2007 it was noted that among the main causes of disability life lost years in the general population were hypertensive diseases [31]. It was estimated that ischemic heart disease rose from 52 deaths per 100,000 population in 1998 to 64 in 2010 Also, that deaths related to cerebrovascular diseases was above $8 \%$, compared with $5 \%$ in the 70 's. Finally, deaths attributable to diabetes increased from $0.4 \%$ in 1960 to $4.4 \%$ in 2012 [32] [34].

In Colombia the possible influence of malnutrition in the first 1000 days of life in the development of NCD's has not been studied neither attempted to estimate. The objective of this study was to estimate the burden of disease of hypertension, obesity and diabetes mellitus II in adults attributable to no-breastfeeding and low birthweight in the period of 1000 days in Colombia. 


\section{Methods}

A Comparative Quantification of Health Risks for calculating population attributable fractions was conducted according to the World Health Organization methodology [35] [36]. Data of interest in relation to risk factors and outcomes was extracted from national databases.Statistical analyses were conducted in Microsoft Excel. The population attributable fraction was calculated after extracting data and creating the database (detailed data analyses described in Section 2.3.2).

In order to be able to apply this methodology, it was assumed (hypothetical assumption) that the adult population of Colombia was exposed during their first 1000 days of life to a lack of breastfeeding and low birth weight (prevalences taken from population based surveys described below).

However, it is known that the exposures could have been higher since these indicators have been gradually progressing according to national surveys. Therefore, it is very likely that the attributable morbidity estimate is underestimated, which reaffirms the importance of studying this issue in the country. Also, in this study the risk factors were treated as dicotomic (having or not having the risk factor) and therefore the no exposure category is the distribution that produced the less risk. These distributions were previously established in other studies and international literature.

\subsection{Variables Description}

The unit of analysis to determine the possible relationship between risk factors in the first 1000 days and the development of obesity, hypertension and diabetes mellitus type II were the departments of Colombia. In this area other assumption is that the values of the association measures employed have equal magnitudes for all departments.

\subsection{Exposure Variables}

No breastfeeding was defined as never having received breastmilk. It was taken from the National Nutrition Survey-ENSIN 2010 [35]. This is a mother self report in a household where a child under 5 years was identified. According to the literature it is known that is not the ideal variable, however is the only source that provides information in all the departments of Colombia. The low birth weight variable was taken also for all the departments of Colombia from the vital statistics of the National Department of Statistics—DANE 2011 [30].

\subsection{Outcome Variables}

Hypertension, diabetes mellitus type II and obesity prevalences were taken from the National Demograpich Survey-ENDS 2010, National Health Survey 2007 and the National Nutrition Survey ENSIN-2010 [28] [29] [31] Table 1.

\subsubsection{PubMed Search-Effect Measures for the Associations of Interest}

Prior to the calculation of the attributable fraction, a PubMed literature search was conducted in August 2014 to identify longitudinal studies that had estimated effect measures (Odds Ratios or Relative Risks) between these nutritional risk factors in the 1000 days and the NCD's of interest.

Cohort, case control or meta-analysis studies that provided an effect measure between the risk factors and NCD's of interest were identified. The search was conducted using key words that included the exposures and outcomes of interest. "breastfeeding” (lack of), "low birth weight” (<2500 grams at birth) and "obesity", "diabetes”, "hypertension” (during adulthood). No date or language restrictions were included.

The search only showed results for 2 of the 6 risk factors described in the literature (low birth weight, micronutrient supplementation during pregnancy, micronutrient deficiencies both in pregnancy and in the first 2 years of life were found, excess maternal weight gain during pregnancy, suboptimal breastfeeding, complementary feeding suboptimal), being not receiving breastfeeding and low birth weight. Therefore, the population attributable fraction was only estimated for these 2 .

Additionally, given that the search retrieved no studies in Colombia, the studies with population similar to the Colombian population were preferably chosen Table 2. A United States cohort study [37] [38] for the association between low birthweight and hypertension (adjusted for age, birth weight and parental history of comorbidity) and diabetes (analysis adjusted for age, BMI and maternal history of comorbidity) was chosen [38]. For the 
Table 1. Prevalences of low birth weight, no breastfeeding, hypertension, diabetes mellitus type II and excess weight.

\begin{tabular}{|c|c|c|c|c|c|c|c|c|}
\hline & & $\begin{array}{l}\text { \% Low } \\
\text { birth weight } \\
\text { in men }\end{array}$ & $\begin{array}{c}\text { \% Low } \\
\text { birth weight } \\
\text { in women }\end{array}$ & $\begin{array}{c}\% \\
\text { Hypertension } \\
\text { in men }\end{array}$ & $\begin{array}{c}\% \\
\text { Hypertension } \\
\text { in womens\& }\end{array}$ & $\begin{array}{c}\% \text { Diabetes } \\
\text { mellitus type } \\
\text { II, both sexes }\end{array}$ & $\begin{array}{c}\text { No } \\
\text { breastfeeding } \\
\text { both sexes }\end{array}$ & $\begin{array}{l}\text { \% Obesity) } \\
\text { both sexes }\end{array}$ \\
\hline \multicolumn{9}{|c|}{$\begin{array}{l}\text { Regions } \\
\text { Atlántica }\end{array}$} \\
\hline & Atlántico & 8.4 & 10.0 & 45.4 & 18.3 & 4.1 & 3.3 & 52.6 \\
\hline & Bolívar & 7.3 & 8.5 & 28.6 & 10.4 & 1.6 & 2.5 & 47.3 \\
\hline & Córdoba & 8.2 & 9.6 & 34.6 & 20.8 & 2.2 & 6.8 & 44.6 \\
\hline & Magdalena & 6.5 & 8.4 & 28.1 & 13.3 & 1.4 & 4.1 & 45.1 \\
\hline & Cesar & 6.7 & 8.3 & 33.5 & 6.4 & 1.4 & 5.4 & 50.6 \\
\hline & La Guajira & 7.6 & 9.1 & 50.7 & 8.9 & 1.7 & 3.6 & 47.9 \\
\hline & Sucre & 7.4 & 8.6 & 46.8 & 25.7 & 2.6 & 7 & 45.9 \\
\hline & $\begin{array}{l}\text { San Andrés y } \\
\text { Providencia }\end{array}$ & 7.3 & 5.7 & 30.0 & 17.4 & 1.5 & 3.6 & 65 \\
\hline \multicolumn{9}{|l|}{ Oriental } \\
\hline & Cundinamarca & 7.2 & 8.7 & 35.5 & 11.6 & 1.9 & 4.9 & 55.4 \\
\hline & Santander & 7.1 & 8.8 & 36.0 & 16.8 & 3.0 & 4.3 & 52 \\
\hline & Boyacá & 8.1 & 9.8 & 36.1 & 6.8 & 1.0 & 3.9 & 52.8 \\
\hline & $\begin{array}{l}\text { Norte de } \\
\text { Santander }\end{array}$ & 5.4 & 6.9 & 63.2 & 19.2 & 4.2 & 3.3 & 49.2 \\
\hline & Meta & 6.2 & 7.5 & 33.3 & 12.9 & 1.2 & 3.7 & 54.2 \\
\hline \multicolumn{9}{|l|}{ Bogotá } \\
\hline & Bogotá & 12.4 & 15.1 & 43.5 & 14.1 & 2.2 & 2.9 & 51.3 \\
\hline \multicolumn{9}{|l|}{ Central } \\
\hline & Antioquia & 8.5 & 10.1 & 34.6 & 17.0 & 3.0 & 4.6 & 49.3 \\
\hline & Tolima & 6.4 & 7.1 & 31.7 & 12.0 & 1.3 & 5.1 & 57.5 \\
\hline & Huila & 6.4 & 6.6 & 41.2 & 18.6 & 1.2 & 2.5 & 55.3 \\
\hline & Caldas & 5.3 & 6.4 & 51.1 & 24.8 & 0.8 & 6.2 & 51.0 \\
\hline & Risaralda & 8.7 & 8.6 & 31.5 & 18.4 & 0.5 & 6.1 & 48.2 \\
\hline & Quindío & 7.3 & 7.5 & 25.8 & 12.9 & 1.4 & 5.8 & 52.3 \\
\hline & Caquetá & 5.7 & 6.7 & 15.1 & 12.4 & 2.1 & 3.9 & 58.8 \\
\hline \multicolumn{9}{|l|}{ Pacífica } \\
\hline & $\begin{array}{l}\text { Valle del } \\
\text { Cauca }\end{array}$ & 8.7 & 9.5 & 46.3 & 21.4 & 3.2 & 4.2 & 53.9 \\
\hline & Nariño & 8.2 & 9.4 & 46.0 & 24.5 & 0.7 & 2.7 & 53.0 \\
\hline & Cauca & 6.8 & 7.5 & 53.4 & 17.1 & 0.9 & 3.3 & 50.6 \\
\hline & Chocó & 6.0 & 10.4 & 51.1 & 34.0 & 4.5 & 4.2 & 47.2 \\
\hline
\end{tabular}




\section{Continued}

Orinoquía y Amazonía

$\begin{array}{cccccccc}\text { Casanare } & 3.4 & 4.5 & 13.4 & 3.6 & 5.0 & 2.1 & 57.9 \\ \text { Putumayo } & 2.8 & 4.0 & 32.9 & 12.6 & 2.1 & 5.3 & 50.1 \\ \text { Arauca } & 4.4 & 6.1 & 38.6 & 16.4 & 2.5 & 3.4 & 56.4 \\ \text { Guaviare } & 5.8 & 5.7 & 29.2 & 21.5 & 0.9 & 4.8 & 62.1 \\ \text { Vichada } & 2.9 & 3.9 & 16.6 & 8.3 & 1.6 & 3.9 & 58.4 \\ \text { Amazonas } & 3.9 & 5.3 & 28.9 & 13.3 & 7.7 & 2.2 & 45.8 \\ \text { Guainía } & 3.3 & 2.4 & 25.0 & 2.0 & 1.9 & 2.6 & 58.9 \\ \text { Vaupés } & 2.8 & 6.6 & 16.7 & 1.4 & 4.0 & 2.0 & 48.2\end{array}$

Registro de estadísticas vitales. DANE 2011; *Hypertensive men 40 - 69 years, Encuesta Nacional de Salud 2007. Pontificia Universidad JaverianaSEI-Ministerio de la Protección Social; Hypertensive women 25 - 54 years, Encuesta Nacional de Salud 2007. Pontificia Universidad Javeriana-SEIMinisterio de la Protección Social; \$Diabetes mellitus type II, 25 - 54 years, Encuesta Nacional de Salud 2007. Pontificia Universidad Javeriana-SEIMinisterio de la Protección Social; Population de 0 - 4 years, both sexes, ENDS $2010^{* *}$; ${ }^{* * *}$ Population 18 - 69 years, both sexes, Encuesta Nacional de Salud 2007. Pontificia Universidad Javeriana-SEI-Ministerio de la Protección Social.

Table 2. Effect measures (OR/RR) search results, PubMed (August 2014).

\begin{tabular}{|c|c|c|c|}
\hline \multirow{2}{*}{$\begin{array}{l}\text { Risk factors in the } \\
\text { first } 1000 \text { days }\end{array}$} & \multicolumn{3}{|c|}{ NCD’s development } \\
\hline & Hypertension & Diabetes Mellitus type & Obesity \\
\hline Low birth weight & $\begin{array}{l}\text { “relative risk” OR “odds ratio” OR } \\
\text { “cohorts group”AND hypertension } \\
\text { AND “birth weight” }\end{array}$ & $\begin{array}{l}\text { "relative risk” OR “odds ratio” OR } \\
\text { "cohorts group” AND diabetes } \\
\text { AND "birth weight" }\end{array}$ & $\begin{array}{l}\text { “relative risk” OR “odds ratio” } \\
\text { OR “cohorts group” AND } \\
\text { obesity AND “birth weight” }\end{array}$ \\
\hline \multirow{3}{*}{$\begin{array}{c}\text { Micronutrient } \\
\text { supplementation }\end{array}$} & 416 results/14 eligible/2 selected & 499 results/18 eligible/1 selected & 308 results $/ 9$ eligible/ 0 selected \\
\hline & $\begin{array}{c}\text { “relative risk” OR “odds ratio” OR } \\
\text { “cohorts group” AND hypertension } \\
\text { AND “supplementation” }\end{array}$ & $\begin{array}{l}\text { “relative risk” OR “odds ratio” OR } \\
\text { “cohorts group”AND diabetes AND } \\
\text { "supplementation” }\end{array}$ & $\begin{array}{l}\text { “relative risk” OR “odds ratio” } \\
\text { OR “cohorts group” AND } \\
\text { obesity AND “supplementation” }\end{array}$ \\
\hline & 86 results/3 eligible/0 selected & 98 results/0 eligible/0 selected & 35 results/0 eligible/0 selected \\
\hline \multirow[t]{2}{*}{$\begin{array}{c}\text { Micronutrient } \\
\text { deficiency }\end{array}$} & $\begin{array}{l}\text { “relative risk” OR “odds ratio” OR } \\
\text { “cohorts group” AND hypertension } \\
\text { AND “micronutrient deficiency” }\end{array}$ & $\begin{array}{l}\text { “relative risk” OR “odds ratio” OR } \\
\text { “cohorts group” AND diabetes } \\
\text { AND “micronutrient deficiency” }\end{array}$ & $\begin{array}{l}\text { “relative risk” OR “odds ratio” } \\
\text { OR “cohorts group” AND obesity } \\
\text { AND “micronutrient deficiency” }\end{array}$ \\
\hline & 0 results/0 eligible/0 selected & 0 results/0 eligible/0 selected & 0 results/0 eligible/0 selected \\
\hline \multirow[t]{2}{*}{$\begin{array}{l}\text { Maternal excess } \\
\text { weight during } \\
\text { pregnancy }\end{array}$} & $\begin{array}{l}\text { “relative risk” OR “odds ratio” OR } \\
\text { “cohorts group” AND hypertension } \\
\text { AND “maternal obesity” }\end{array}$ & $\begin{array}{l}\text { “relative risk” OR “odds ratio”OR } \\
\text { “cohorts group” AND diabetes } \\
\text { AND “maternal obesity” }\end{array}$ & $\begin{array}{l}\text { “relative risk” OR “odds ratio” } \\
\text { OR “cohorts group” AND obesity } \\
\text { AND “maternal obesity” }\end{array}$ \\
\hline & 21 results/ 0 eligible $/ 0$ selected & 61 results/0 eligible/0 selected & 154 results/0 eligible/0 selected \\
\hline \multirow[t]{2}{*}{$\begin{array}{c}\text { Suboptimal } \\
\text { breastfeeding }\end{array}$} & $\begin{array}{l}\text { "relative risk” OR “odds ratio” OR } \\
\text { “cohorts group” AND hypertension } \\
\text { AND "breastfeeding }\end{array}$ & $\begin{array}{l}\text { "relative risk” OR “odds ratio” OR } \\
\text { "cohorts group” AND diabetes } \\
\text { AND "breastfeeding” }\end{array}$ & $\begin{array}{l}\text { Relative risk OR “odds ratio” } \\
\text { OR “cohorts group” AND obesity } \\
\text { AND “breastfeeding” }\end{array}$ \\
\hline & 22 results/0 eligible/0 selected & 41 results / 2 eligible/ 0 selected & 452 results /4 eligible/1 selected \\
\hline \multirow[t]{2}{*}{$\begin{array}{l}\text { Suboptimal } \\
\text { complementary } \\
\text { feeding }\end{array}$} & $\begin{array}{l}\text { “relative risk” OR “odds ratio” OR } \\
\text { “cohorts group” AND hypertension } \\
\text { AND “complementary feeding” }\end{array}$ & $\begin{array}{l}\text { “relative risk” OR “odds ratio” OR } \\
\text { “cohorts group” AND diabetes } \\
\text { AND “complementary feeding” }\end{array}$ & $\begin{array}{l}\text { “relative risk” OR “odds ratio” } \\
\text { OR “cohorts group” AND obesity } \\
\text { AND “complementary feeding” }\end{array}$ \\
\hline & 0 results/0 eligible/0 selected & 0 results/0 eligible/0 selected & 2 results/0 eligible/0 selected \\
\hline Total & 545 results/17 eligible/2 selected & 699 results/20 eligible/1 selected* & 951 results/13 eligible/1 selected \\
\hline
\end{tabular}

\footnotetext{
*This study reports both hypertension and diabetes mellitus type 2 as outcomes.
} 
association between obesity and not breastfeeding data from a Brazilian cohort (adjusted for age, sex, weight and height in adulthood) [39] was used. This represented a limitation (caution needed when interpreting the results because of the expected demographic differences) for the result interpretation and is discussed in detail in the discussion section. Table 3 studies and association measures used are described.

This study was classified as a study as safe according to the resolution 1993008430 of the Colombian Ministry of Health. The study was submitted and approved by the ethics committee of the School of Government at the University of the Andes in Bogota, Colombia.

\subsubsection{Population Attributable Fraction and Attributable Cases}

Attributable risk is defined as the proportion of disease in exposed individuals that can be attributed to the exposure and is interpreted as the reduced risk of disease that would be achieved by eliminating or controlling a particular exposure (quantified as a percentage). From the attributable risk the number of people who would suffer the consequences of the exposure can be estimated Table 4 .

The estimate was performed with the following equation [35]: $\mathrm{PAF}=(P(R R-1)) /(P(R R-1)+1)$.

$P=$ prevalence of the risk factor. RR is the effect measure from the PubMed search.

Attributable cases were estimated with the following equation $=\mathrm{PAF} *$ number of disease cases $=$ disease cases due to the risk factor.

These cases would be the proportional disease reduction, which would occur if exposure to the risk factor was reduced to zero Table 4.

Finally, maps of Colombia with exposure levels, PAF's and attributed cases were performed using ArcGIS 10.1 software, in order to obtain a spatial view of the problem and locate the most affected regions which could be most benefited with interventions and public policy.

\section{Results}

In relation to the outcomes, it was found that: 1$)$ the prevalence of having ever been breastfed in life in population $0-4$ years in the departments of Colombia was above 95\% (SD 1.35). The prevalence of low birth weight $(<2500$ grams) in men was 6.5\% (SD 2.09) and in women was 7.7\% (SD 2.39) Table 1.

In relation to the outcomes, it was found that the prevalence of overweight and obesity in people aged 18 - 64 years was on average $52.4 \%$ (SD 5.03). The prevalence of hypertension in men 40 - 69 years was $35.6 \%$ (SD 11.8) and women aged 25 - 54 was $15.0 \%$ (SD 7.13). 3) The prevalence of type 2 diabetes mellitus in the population of 24 - 54 years of age in both sexes was 2.3\% (SD 1.53) Table 1.

It was determined that it not receiving breastfeeding could contribute to $29.9 \%$ of all cases of obesity (ranging from $28.7 \%$ to $30.8 \%$ ), calculating up to 4,009,779 cases attributed nationwide. Table 5 and Figure 1 contains the department results.

Table 3. Selected effect measures for the estimation of the population attributable fraction.

\begin{tabular}{|c|c|c|c|c|c|c|}
\hline \multirow[b]{3}{*}{ Study name } & \multirow[b]{3}{*}{ Reference } & \multirow[b]{3}{*}{$\begin{array}{c}\text { Risk } \\
\text { factors }\end{array}$} & \multicolumn{4}{|c|}{ Outcomes } \\
\hline & & & \multicolumn{2}{|c|}{ Hypertension } & \multirow{2}{*}{$\begin{array}{c}\text { Diabetes } \\
\text { mellitus type II } \\
\text { Both sexes } \\
\text { (25 a } 55 \text { years) }\end{array}$} & \multirow{2}{*}{$\begin{array}{c}\text { Obesity } \\
\text { Both sexes } \\
\text { (15 - } 41 \text { years })\end{array}$} \\
\hline & & & $\begin{array}{c}\text { Men } \\
\text { (40 a } 75 \text { years) }\end{array}$ & $\begin{array}{c}\text { Women } \\
\text { (25 a } 55 \text { years) }\end{array}$ & & \\
\hline $\begin{array}{l}\text { —Birth Weight and Adult } \\
\text { Hypertension, Diabetes Mellitus, } \\
\text { and Obesity in US Men. } \\
\text { —Birth Weight and Adult } \\
\text { Hypertension and Obesity in } \\
\text { Women. }\end{array}$ & 37 & $\begin{array}{l}\text { Bajo peso } \\
(2500 \mathrm{~g} \text { or } \\
\text { less })\end{array}$ & $\begin{array}{c}1.26 \text { (95\% CI, } 1.11 \\
-1.44)\end{array}$ & $\begin{array}{c}1.43(95 \% \mathrm{CI}, \\
1.31-1.56)\end{array}$ & $\begin{array}{c}1.75(95 \% \mathrm{CI}, \\
1.51-2.03)\end{array}$ & NA \\
\hline $\begin{array}{l}\text {-Infant-feeding patterns and } \\
\text { cardiovascular risk factors in } \\
\text { young adulthood: data from } \\
\text { five cohorts in low- and } \\
\text { middle-income countries. }\end{array}$ & 37 & $\begin{array}{l}\text { Breastfeeding } \\
\text { (at least once } \\
\text { in life) }\end{array}$ & NA & & NA & $\begin{array}{c}0.76 \\
(95 \% \text { CI, } 0.59-0.98)\end{array}$ \\
\hline
\end{tabular}


Table 4. Colombia departaments with more attributable morbidity due to risk factors in the first 1000 days of life.

\begin{tabular}{|c|c|c|c|c|c|c|c|c|}
\hline & Obesity & $\%$ & Hypertension in men & $\%$ & Hypertension in women & $\%$ & Diabetes mellitus type 2 & $\%$ \\
\hline 1 & Vaupés & 30.8 & Bogotá & 3.1 & Bogotá & 6.1 & Bogotá & 9.3 \\
\hline 2 & Casanare & 30.7 & Risaralda & 2.2 & Antioquia & 4.1 & Antioquia & 6.5 \\
\hline 3 & Amazonas & 30.7 & Valle del Cauca & 2.2 & Atlántico & 4.1 & Atlántico & 6.5 \\
\hline 4 & Bolívar & 30.5 & Antioquia & 2.2 & Boyacá & 4.0 & Valle del Cauca & 6.4 \\
\hline 5 & Huila & 30.5 & Atlántico & 2.1 & Córdoba & 4.0 & Boyacá & 6.3 \\
\hline 6 & Guainía & 30.5 & Nariño & 2.1 & Valle del Cauca & 3.9 & Córdoba & 6.2 \\
\hline 7 & Nariño & 30.5 & Córdoba & 2.1 & Nariño & 3.9 & Nariño & 6.2 \\
\hline 8 & Bogotá & 30.4 & Boyacá & 2.1 & La Guajira & 3.8 & Risaralda & 6.1 \\
\hline 9 & Atlántico & 30.2 & La Guajira & 1.9 & Santander & 3.6 & La Guajira & 5.9 \\
\hline 10 & Cauca & 30.2 & Sucre & 1.9 & Cundinamarca & 3.6 & Chocó & 5.8 \\
\hline 11 & Norte de Santander & 30.2 & $\begin{array}{l}\text { San Andrés y } \\
\text { Providencia }\end{array}$ & 1.9 & Risaralda & 3.6 & Sucre & 5.6 \\
\hline 12 & Arauca & 30.2 & Bolívar & 1.9 & Sucre & 3.6 & Cundinamarca & 5.6 \\
\hline 13 & La Guajira & 30.1 & Quindío & 1.9 & Bolívar & 3.5 & Santander & 5.6 \\
\hline 14 & San Andrés y Providencia & 30.1 & Cundinamarca & 1.8 & Magdalena & 3.5 & Bolívar & 5.6 \\
\hline 15 & Meta & 30.1 & Santander & 1.8 & Cesar & 3.4 & Cesar & 5.3 \\
\hline 16 & Boyacá & 30.0 & Cauca & 1.7 & Chocó & 3.4 & Magdalena & 5.3 \\
\hline 17 & Caquetá & 30.0 & Cesar & 1.7 & Cauca & 3.1 & Quindío & 5.2 \\
\hline 18 & Vichada & 30.0 & Chocó & 1.7 & Meta & 3.1 & Cauca & 5.1 \\
\hline 19 & Magdalena & 29.9 & Magdalena & 1.7 & Quindío & 3.1 & Meta & 4.9 \\
\hline 20 & Chocó & 29.9 & Tolima & 1.6 & Tolima & 2.9 & Tolima & 4.8 \\
\hline 21 & Valle del Cauca & 29.9 & Huila & 1.6 & Norte de Santander & 2.9 & San Andrés y Providencia & 4.7 \\
\hline 22 & Santander & 29.8 & Meta & 1.6 & Caquetá & 2.8 & Huila & 4.6 \\
\hline 23 & Antioquia & 29.7 & Guaviare & 1.5 & Huila & 2.8 & Caquetá & 4.4 \\
\hline 24 & Guaviare & 29.6 & Caquetá & 1.5 & Vaupés & 2.7 & Norte de Santander & 4.4 \\
\hline 25 & Cundinamarca & 29.6 & Norte de Santander & 1.4 & Caldas & 2.7 & Caldas & 4.2 \\
\hline 26 & Tolima & 29.5 & Caldas & 1.4 & Arauca & 2.5 & Guaviare & 4.1 \\
\hline 27 & Putumayo & 29.4 & Arauca & 1.1 & Guaviare & 2.4 & Arauca & 3.8 \\
\hline 28 & Cesar & 29.4 & Amazonas & 1.0 & San Andrés y Providencia & 2.4 & Vaupés & 3.4 \\
\hline 29 & Quindío & 29.2 & Casanare & 0.9 & Amazonas & 2.2 & Amazonas & 3.3 \\
\hline 30 & Risaralda & 29.1 & Guainía & 0.8 & Casanare & 1.9 & Casanare & 2.9 \\
\hline 31 & Caldas & 29.1 & Vichada & 0.8 & Putumayo & 1.7 & Vichada & 2.5 \\
\hline 32 & Córdoba & 28.8 & Vaupés & 0.7 & Vichada & 1.7 & Putumayo & 2.5 \\
\hline 33 & Sucre & 28.7 & Putumayo & 0.7 & Guainía & 1.0 & Guainía & 2.1 \\
\hline
\end{tabular}

Highlighted in gray are the departments that were at least in the first 10 departments with highest population attributable fraction. 
Table 5. Population attributable fraction of NCDs due to risk factors in the first 1000 days of life.

\begin{tabular}{|c|c|c|c|c|c|c|c|c|}
\hline & \multicolumn{3}{|c|}{ Obesity } & \multicolumn{3}{|c|}{ Hypertension } & \multicolumn{2}{|c|}{ Diabetes mellitus type 2} \\
\hline & \multirow[b]{2}{*}{$\%$} & \multirow[b]{2}{*}{ Attributable cases } & \multicolumn{2}{|r|}{ Men } & \multicolumn{2}{|r|}{ Women } & \multirow[b]{2}{*}{$\%$} & \multirow[b]{2}{*}{ Attributable cases } \\
\hline & & & $\%$ & Attributable cases & $\%$ & Attributable cases & & \\
\hline \multicolumn{9}{|c|}{ Regions } \\
\hline \multicolumn{9}{|c|}{ Atlántica } \\
\hline Atlántico & 30.2 & 214,704 & 2.1 & 2815 & 4.1 & 3562 & 6.5 & 2211 \\
\hline Bolívar & 30.5 & 155,427 & 1.9 & 1280 & 3.5 & 1364 & 5.6 & 649 \\
\hline Córdoba & 28.8 & 107,472 & 2.1 & 1047 & 4.0 & 2553 & 6.2 & 746 \\
\hline Magdalena & 29.9 & 82,639 & 1.7 & 557 & 3.5 & 1080 & 5.3 & 308 \\
\hline Cesar & 29.4 & 74,161 & 1.7 & 548 & 3.4 & 406 & 5.3 & 237 \\
\hline La Guajira & 30.1 & 58,578 & 1.9 & 431 & 3.8 & 548 & 5.9 & 232 \\
\hline Sucre & 28.7 & 56,922 & 1.9 & 850 & 3.6 & 1326 & 5.6 & 427 \\
\hline San Andrés y Providencia & 30.1 & 8677 & 1.9 & 67 & 2.4 & 87 & 4.7 & 29 \\
\hline \multicolumn{9}{|c|}{ Oriental } \\
\hline Cundinamarca & 29.6 & 230,712 & 1.8 & 1935 & 3.6 & 1974 & 5.6 & 879 \\
\hline Santander & 29.8 & 183,199 & 1.8 & 1354 & 3.6 & 2706 & 5.6 & 1232 \\
\hline Boyacá & 30.0 & 110,554 & 2.1 & 1262 & 4.0 & 710 & 6.3 & 276 \\
\hline Norte de Santander & 30.2 & 106,112 & 1.4 & 1251 & 2.9 & 1422 & 4.4 & 844 \\
\hline Meta & 30.1 & 79,860 & 1.6 & 492 & 3.1 & 765 & 4.9 & 190 \\
\hline \multicolumn{9}{|c|}{ Bogotá } \\
\hline Bogotá & 30.4 & 717,177 & 3.1 & 10,963 & 6.1 & 13,794 & 9.3 & 5877 \\
\hline \multicolumn{9}{|c|}{ Central } \\
\hline Antioquia & 29.7 & 531,231 & 2.2 & 5516 & 4.1 & 8356 & 6.5 & 4368 \\
\hline Tolima & 29.5 & 130,295 & 1.6 & 1048 & 2.9 & 1417 & 4.8 & 400 \\
\hline Huila & 30.5 & 97,997 & 1.6 & 840 & 2.8 & 1072 & 4.6 & 214 \\
\hline Caldas & 29.1 & 86,004 & 1.4 & 829 & 2.7 & 1502 & 4.2 & 131 \\
\hline Risaralda & 29.1 & 77,632 & 2.2 & 958 & 3.6 & 1326 & 6.1 & 101 \\
\hline Quindío & 29.2 & 49,969 & 1.9 & 331 & 3.1 & 565 & 5.2 & 157 \\
\hline Caquetá & 30.0 & 40,092 & 1.5 & 94 & 2.8 & 283 & 4.4 & 137 \\
\hline \multicolumn{9}{|c|}{ Pacífica } \\
\hline Valle del Cauca & 29.9 & 425,177 & 2.2 & 4605 & 3.9 & 8038 & 6.4 & 3115 \\
\hline Nariño & 30.5 & 145,985 & 2.1 & 1852 & 3.9 & 3254 & 6.2 & 251 \\
\hline Cauca & 30.2 & 109,267 & 1.7 & 1051 & 3.1 & 1511 & 5.1 & 199 \\
\hline Chocó & 29.9 & 30,180 & 1.7 & 548 & 3.4 & 406 & 5.8 & 403 \\
\hline \multicolumn{9}{|c|}{ Orinoquía y Amazonía } \\
\hline Casanare & 30.7 & 31,150 & 0.9 & 22 & 1.9 & 31 & 2.9 & 124 \\
\hline Putumayo & 29.4 & 23,706 & 0.7 & 26 & 1.7 & 62 & 2.5 & 27 \\
\hline Arauca & 30.2 & 20,258 & 1.1 & 53 & 2.5 & 123 & 3.8 & 49 \\
\hline Guaviare & 29.6 & 9026 & 1.5 & 19 & 2.4 & 65 & 4.1 & 7 \\
\hline Vichada & 30.0 & 4960 & 0.8 & 3 & 1.7 & 7 & 2.5 & 3 \\
\hline Amazonas & 30.7 & 4661 & 1.0 & 6 & 2.2 & 20 & 3.3 & 25 \\
\hline Guainía & 30.5 & 3198 & 0.8 & 3 & 1.0 & 0.5 & 2.1 & 2 \\
\hline Vaupés & 30.8 & 2801 & 0.7 & 2 & 2.7 & 1 & 3.4 & 7 \\
\hline Total & 29.9 & $4,009,779$ & 2.1 & 42,377 & 4.0 & 61,392 & 6.3 & 23,857 \\
\hline
\end{tabular}




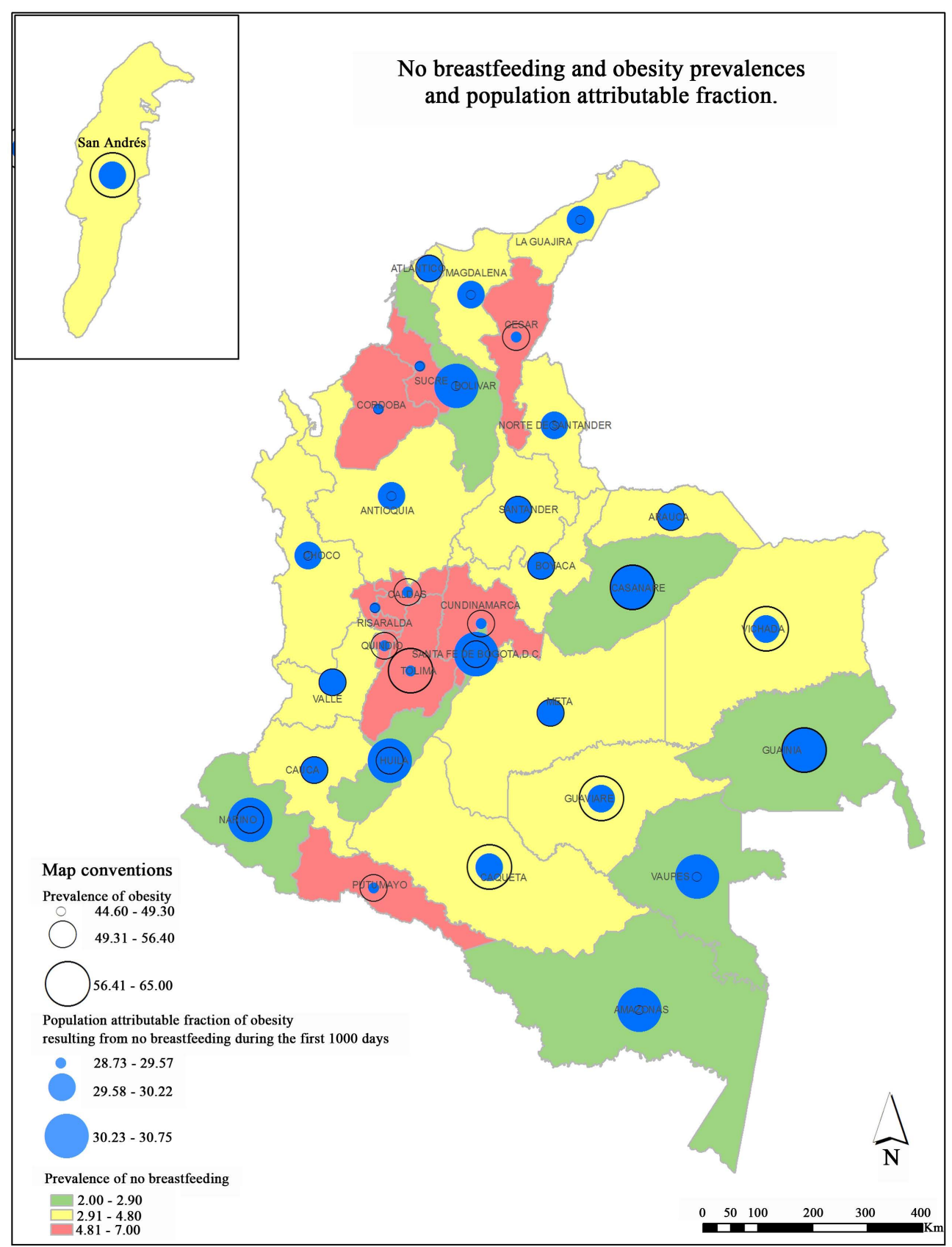

Figure 1. No breastfeeding and obesity prevalences and population attributable fraction.

On the map the prevalence of overweight and obesity (represented by circles with black contour color), the fraction of overweight and obesity attributable to non-breastfeeding (represented with blue circles), and the prevalence of not breastfeeding (represented by background colors in the departments) are compared. Red colors show the prevalence of non-breastfeeding, on the other hand the difference between black and blue circles shows the ratio of prevalence and the proportion of attributable overweight and obesity.

Additionally it was determined that low birth weight could contribute up to $2.1 \%$ of cases of hypertension in men (ranging from $0.7 \%$ to $3.1 \%$ ) and in women up to $4.0 \%$ of cases of hypertension (ranging from $1.0 \%$ to $6.1 \%$ ). This is equivalent to 103.769 cases across the country Table 4 and Figure 2. For type 2 diabetes mellitus is was estimated low birth weight may contribute to $6.3 \%$ of cases (ranging from $2.1 \%$ to $9.3 \%$ ), equivalent to 23.857 cases throughout the country Table 5 and Figure 3. 


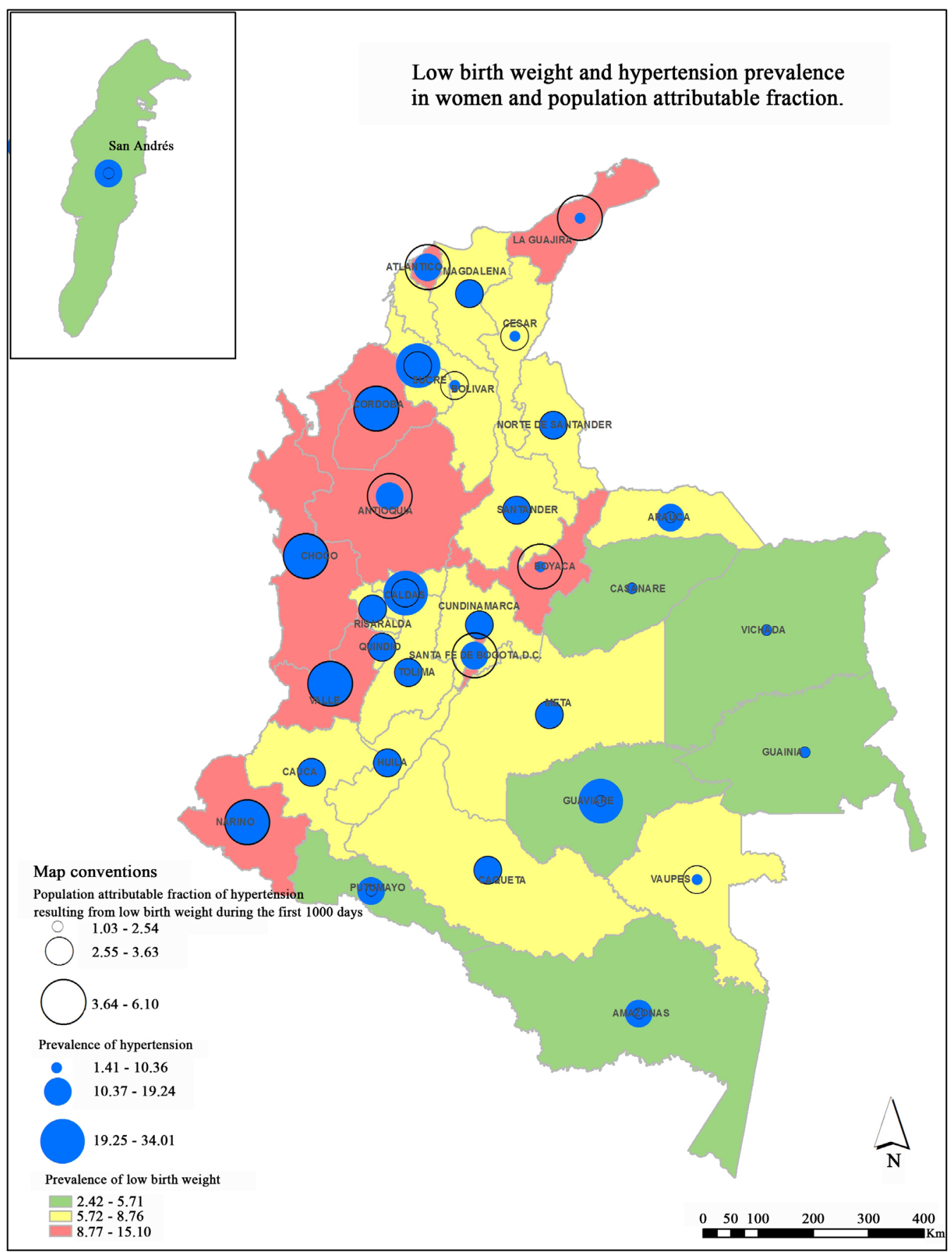

Figure 2. Low birth weight and hypertension prevalence in women, and population attributable fraction.

When comparing morbidity due to obesity, hypertension and diabetes mellitus type 2 attributable to these nutritional risk factors, Bogotá, Antioquia, Atlántico, Boyacá, Valle del Cauca, Nariño and Guajira are among the top 10 departments with increased attributable morbidity Table 4.

In the departments of Guainia, Casanare, Atlantic, Valle, Cauca, Santander, Boyaca and Meta it was observed that most of the obesity morbidity is attributed to non-breastfeeding. In Antioquia and Valle is where most cases are attributed and therefore potentially avoided.

In the departments of Atlántico, Cesar, Bolivar, Santander, Bogota, Valle, Quindio, Tolima, Nariño, Guaviare, Casanare and Vichada most of the morbidity from hypertension in men is attributed to low birth weight. And in 


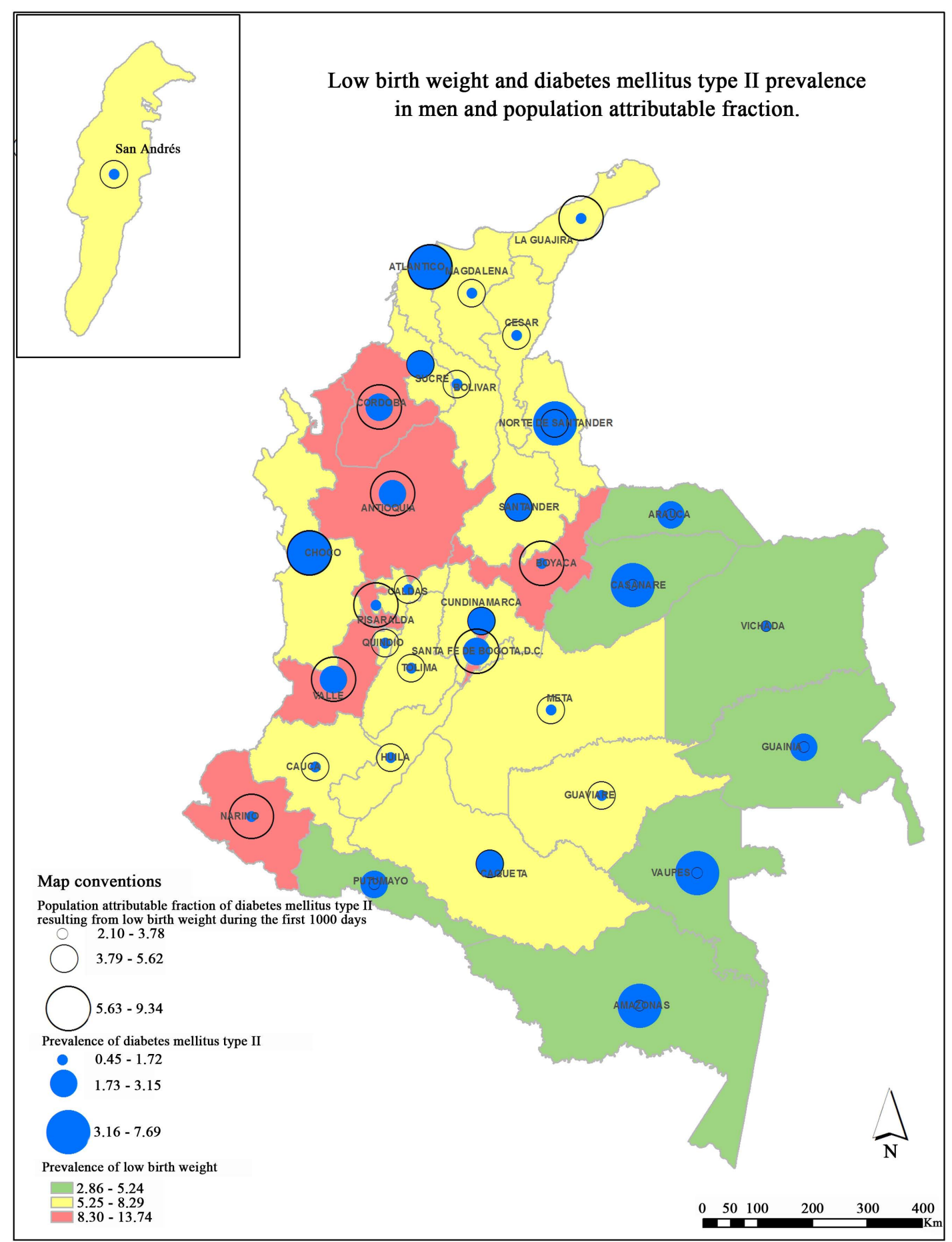

Figure 3. Low birth weight and diabetes mellitus type II prevalence in men, and population attributable fraction.

women it is in the departments of Cordoba, Chocó, Valle, Narino, Cauca, Tolima, Quindio, Huila, Caqueta, Norte de Santander and Santander, Meta and Magdalena.

In the departments of Atlantico, Choco, Santander, Sucre and Boyaca it is observed that most of the morbidity from diabetes mellitus type 2 is attributed to low birth weight.

In general, in the maps a difference between the Andean, Orinoco and Amazon regions can be observed. Furthermore, Antioquia,Valle and eje cafetero appear to be different from the rest of the country. 


\section{Discussion}

This is the first study in Colombia that showed that risk factors in the period of 1000 days like not receiving breastfeeding and having low birth weight could contribute up to 4,113,549 cases of obesity, hypertension and diabetes mellitus II in adulthood.

Therefore, this study confirmed the importance of preventing nutritional risk factors during the 1000 days of life to potentially prevent the development of NCD's such as obesity, hypertension and diabetes mellitus type II.

According to the literature, we know that having these risk factors and living in environments where metabolic disorders are prevalent contribute to the development of chronic diseases [23]-[26]. Therefore, in addition to determining the importance of preventing nutritional risk factors and promoting proper breastfeeding in the 1000 days of life, attention should also be payed to the populations living in the departments where the prevalence of chronic diseases are higher.

While it should be noted that the development of chronic disease is a multifactorial process, it is clear that the likelihood of developing them could be reduced if risk factors at all stages of life were prevented, specially at an important life period as the 1000 days. While literature shows many studies describing the association and the burden of disease among risk factors in adulthood (have a high fat diet, smoking and being physically inactive) and the development of chronic diseases $(1,39,40)$, there are few and some inconclusive studies about the magnitude and impact on health of risk factors in early life and the development of NCD's with measures of disease burden and population attributable fraction or DALYs. The World Health Organization's 2008 health burden study is the only study that has estimated that suboptimal breastfeeding is among the top 10 risk factors to have more disability life lost years (DALYs) [40].

One of the major findings of this study is the lack of updated evidence in the Latin American region about the association between nutritional risk factors in the 1000 days of life and the development of key causes of mortality in the region countries. It is essential to generate local evidence to solve the health problems of the region.

The following methodological aspects should be taken into account as study limitations. In order to calculate the population attributable risk was necessary to use measures of association between the risk factor and the outcome of interest. Therefore, it was noted that studies meeting these inclusion criteria are very limited and practically nonexistent in Colombia and Latin America except for the studies Brazilian cohorts. Therefore the results need to be interpreted with caution, since underestimation and measurement errors are possible (in the case of diseases with a naturally long history, foreign cohorts may have a cumulative level of exposure different than the Colombian population). Additionally the difficulty to find studies with effect measures to be able to estimate the population attributable fraction and cases was a challenge and it was not possible to perform a metanalyses and calculate a pooled estimator. Finally, not having enough local data to determine exposure to risk factors also limited the application of the methodology to specific age groups, which suggests that the attributable fraction should be interpreted with caution.

From an epidemiological perspective, it is known that this type of study involving variables in distant periods of life (intrauterine/perinatal and adolescence/adulthood exposures) is subject to a number of analytical problems, which does not mean they can not contribute to knowledge in the field of health in the life cycle. Known limitations include lack of measurements throughout life (BMI) and genetic factors, biological and socioeconomic confusion variables.

Specifically in the case of diabetes mellitus type II and hypertension in women the association was found for a group of young people of 20 - 54 years which could underestimate the true burden of disease because in this case the prevalence of diabetes for both sexes women and hypertension were relatively low. Natural history of chronic diseases are known to begin and to be diagnosed at later ages. In the case of not having been breastfed the limitation was that the risk factor was very general (the survey question asked about ever giving breastfeeding in life).

It should be noted that even though the brestfeeding variable was general, having breastfed at least once in life showed potential benefits on the control of the epidemic of chronic diseases. It is important to emphasize that breastfeeding should be practiced as determined in the international recommendations and if practiced properly could still provide more benefits on the control of NCDs in the country. Despite these limitations and according to the recommendations of the studies found, determining morbidity due to preventable risk factors in developing countries like Colombia is a public health priority. The literature shows common regional challenges in health and nutrition. 
Therefore the results of this study are relevant to decision makers to get a perspective of the possible health impact of interventions to promote optimal breastfeeding conducted in accordance with international recommendations and to prevent low birth weight in the departments of Colombia. Is required to address these issues in the formulation of public policies at the national level, in addition, the use of spatialized indicators allows decision makers to guide and coordinate policies and programs and conduct regional alliances.

\section{Conclusion}

This study showed that promoting optimal breastfeeding and preventing low birth weight in the Colombian population could prevent potential cases of obesity, hypertension and diabetes mellitus type 2 in adulthood, with important implications for the health of the population and the Colombian health system.

\section{Acknowledgements}

Deborah Salvo from Texas University in Austin; Kenny Trujillo from Centro de Estudios e Investigación en Salud-CEIS; Luis Jorge Hernández from Universidad de los Andes; Jenny Milena Machetá, Diego Prieto and Giovanni Hernandez of the Biblioteca Satélite de Medicina de la Universidad de los Andes

\section{Conflicts of Interest}

There are no conflicts of interest..

\section{References}

[1] World Health Organization (WHO) (2008) The Global Burden of Disease. http://www.who.int/healthinfo/global_burden_disease/2004_report_update/en/

[2] Miranda, J.J., Kinra, S., Casas, J.P., Davey Smith, G. and Ebrahim, S. (2008) Non-Communicable Diseases in Lowand Middle-Income Countries: Context, Determinants and Health Policy. Tropical Medicine \& International Health, 13, 1225-1234. http://dx.doi.org/10.1111/j.1365-3156.2008.02116.x

[3] Institute of Medicine (US) Committee on Preventing the Global Epidemic of Cardiovascular Disease: Meeting the Challenges in Developing Countries, Fuster, V. and Kelly, B.B., Eds. (2010) Promoting Cardiovascular Health in the Developing World: A Critical Challenge to Achieve Global Health. National Academies Press (US), Washington DC. http://www.ncbi.nlm.nih.gov/books/NBK45693/

[4] World Health Organization (WHO) (2003) Diet, Nutrition and the Prevention of Chronic Diseases. http://www.who.int/dietphysicalactivity/publications/trs916/download/en/

[5] Adair, L.S. (2014) Long-Term Consequences of Nutrition and Growth in Early Childhood and Possible Preventive Interventions. Nestlé Nutrition Institute Workshop Series, 78, 111-120. http://dx.doi.org/10.1159/000354949

[6] Canani, R.B., Costanzo, M.D., Leone, L., Bedogni, G., Brambilla, P., Cianfarani, S., et al. (2011) Epigenetic Mechanisms Elicited by Nutrition in Early Life. Nutrition Research Reviews, 24, 198-205. http://dx.doi.org/10.1017/S0954422411000102

[7] Delisle, H. (2002) Foetal Programming of Nutrition-Related Chronic Diseases. Sante, 12, 56-63.

[8] Langley-Evans, S.C. and McMullen, S. (2010) Developmental Origins of Adult Disease. Medical Principles and Practice, 19, 87-98. http://dx.doi.org/10.1159/000273066

[9] Uauy, R., Albala, C. and Kain, J. (2001) Obesity Trends in Latin América: Transiting from under to Overweight. Journal of Nutrition, 131, 893S-899S.

[10] Albala, C., Vio, F., Kain, J. and Uauy, R. (2001) Nutrition Transition in Latin America: The Case of Chile. Nutrition Reviews, 59, 170-176. http://dx.doi.org/10.1111/j.1753-4887.2001.tb07008.x

[11] Uauy, R., Kain, J. and Corvalan, C. (2011) How Can the Developmental Origins of Health and Disease (DOHaD) Hypothesis Contribute to Improving Health in Developing Countries? The American Journal of Clinical Nutrition, 94, 1759S-1764S. http://dx.doi.org/10.3945/ajcn.110.000562

[12] Barría, R.M. and Amigo, H. (2006) Nutrition Transition: A Review of Latin American Profile. Archivos Latinoamericanos de Nutrición, 56, 3-11.

[13] Bermudez, O.I. and Tucker, K.L. (2003) Trends in Dietary Patterns of Latin American Populations. Cadernos de Saúde Pública, 19, S87-S99. http://dx.doi.org/10.1590/S0102-311X2003000700010

[14] UNICEF (2013) Improving Child Nutrition: The Achievable Imperative for Global Progress. 
http://www.unicef.org/publications/index_68661.html

[15] Bhutta, Z.A., et al. (2013) Evidence-Based Interventions for Improvement of Maternal and Child Nutrition: What Can Be Done and at What Cost? The Lancet, 382, 452-477. http://dx.doi.org/10.1016/s0140-6736(13)60996-4

[16] Brenseke, B., Prater, M.R., Bahamonde, J. and Gutierrez, J.C. (2013) Current Thoughts on Maternal Nutrition and Fetal Programming of the Metabolic Syndrome. Journal of Pregnancy, 2013, Article ID: 368461. http://dx.doi.org/10.1155/2013/368461

[17] Yang, Z. and Huffman, S.L. (2013) Nutrition in Pregnancy and Early Childhood and Associations with Obesity in Developing Countries. Maternal \& Child Nutrition, 9, 105-119. http://dx.doi.org/10.1111/mcn.12010

[18] Curhan, G.C., Chertow, G.M., Willett, W.C., Spiegelman, D., Colditz, G.A., Manson, J.E., Speizer, F.E. and Stampfer, M.J. (1996) Birth Weight and Adult Hypertension and Obesity in Women. Circulation, 94, 1310-1315. http://dx.doi.org/10.1161/01.cir.94.6.1310

[19] Shields, L., Mamun, A.A., O’Callaghan, M., Williams, G.M. and Najman, J.M. (2010) Breastfeeding and Obesity at 21 Years: A Cohort Study. Journal of Clinical Nursing, 19, 1612-1617. http://dx.doi.org/10.1111/j.1365-2702.2009.03015.x

[20] Christian, P. and Stewart, C.P. (2010) Maternal Micronutrient Deficiency, Fetal Development, and the Risk of Chronic Disease. Journal of Nutrition, 140, 437-445. http://dx.doi.org/10.3945/jn.109.116327

[21] Fall, C.H. (2013) Fetal Malnutrition and Long-Term Outcomes. http://www.karger.com/Article/Abstract/348384

[22] Fall, C.H. (2013) Fetal Programming and the Risk of Noncommunicable Disease. The Indian Journal of Pediatrics, 80, 13-20. http://dx.doi.org/10.1007/s12098-012-0834-5

[23] Gluckman, P.D., Hanson, M.A. and Beedle, A.S. (2007) Early Life Events and Their Consequences for Later Disease: A Life History and Evolutionary Perspective. American Journal of Human Biology, 19, 1-19. http://dx.doi.org/10.1002/ajhb.20590

[24] Henriksen, T., Haugen, G., Bollerslev, J., Kolset, S.O., Drevon, C.A., Iversen, P.O., et al. (2005) Fetal Nutrition and Future Health. Tidsskr Nor Laegeforen, 125, 442-444.

[25] Barker, D.J.P. (2012) Developmental Origins of Chronic Disease. Public Health, 126, 185-189. http://dx.doi.org/10.1016/j.puhe.2011.11.014

[26] Lutter, C.K. and Lutter, R. (2012) Fetal and early Childhood Undernutrition, Mortality, and Lifelong Health. Science, 337, 1495-1499. http://dx.doi.org/10.1126/science.1224616

[27] World Health Organization (WHO) (2001) The Optimal Duration of Exclusive Breastfeeding. http://www.who.int/nutrition/publications/infantfeeding/WHO_NHD_01.09/en/

[28] Familiar ICdB. Encuesta Nacional de Situación Nutricional en Colombia (ENSIN) 2010. http://www.icbf.gov.co/portal/page/portal/PortalICBF/Bienestar/ENSIN1

[29] Profamilia APdlFC-Encuesta Nacional de Demografía y Salud (ENDS) 2010. http://microdata.worldbank.org/index.php/catalog/1361

[30] Departamento Administrativo Nacional de Estadística (DANE) (2010) Estadísticas vitales 2011. http://www.dane.gov.co/

[31] Encuesta Nacional de Salud (2007) Pontificia Universidad Javeriana-SEI-Ministerio de la Protección Social. http://www.scp.com.co/ArchivosSCP/Encuesta_Nacional_de_Salud_2007.pdf

[32] Análisis de la situación de salud de Colombia (2013) Tomo III, Morbilidad y Mortalidad de la población Colombiana.

[33] Instituto Nacional de Salud (2013) Observatorio Nacional de Salud, Boletín 1 Diciembre de 2013. http://www.ins.gov.co/lineas-de-accion/ons/boletin\%201/boletin_web_ONS/boletin_01_ONS.pdf

[34] Análisis de la situación de salud de Colombia (2002-2007) Tomo III, Morbilidad y Mortalidad de la población Colombiana.

[35] Murray, C.J., Ezzati, M., Lopez, A.D., Rodgers, A. and Vander Hoorn, S. (2003) Comparative Quantification of Health Risks Conceptual Framework and Methodological Issues. Population Health Metrics, 1, 1. http://dx.doi.org/10.1186/1478-7954-1-1

[36] World Health Organization (WHO) (2013) WHO Methods and Data Sources for Global Burden of Disease Estimates 2000-2011. http://www.who.int/healthinfo/statistics/GlobalDALYmethods 2000 2011.pdf?ua=1

[37] Curhan, G.C., Willett, W.C., Rimm, E.B., Spiegelman, D., Ascherio, A.L. and Stampfer, M.J. (1996) Birth Weight and Adult Hypertension, Diabetes Mellitus, and Obesity in US Men. Circulation, 94, 3246-3250. http://dx.doi.org/10.1161/01.CIR.94.12.3246

[38] Curhan, G.C., Chertow, G.M., Willett, W.C., Spiegelman, D., Colditz, G.A., Manson, J.E., Speizer, F.E. and Stampfer, 
M.J. (1996) Birth Weight and Adult Hypertension and Obesity in Women. Circulation, 94, 1310-1315. http://dx.doi.org/10.1161/01.CIR.94.6.1310

[39] Fall, C.H., Borja, J.B., Osmond, C., Richter, L., Bhargava, S.K., Martorell, R., Stein, A.D., Barros, F.C. and Victora, C.G., COHORTS Group (2011) Infant-Feeding Patterns and Cardiovascular Risk Factors in Young Adulthood: Data from Five Cohorts in Low- and Middle-Income Countries. International Journal of Epidemiology, 40, 47-62. http://dx.doi.org/10.1093/ije/dyq155

[40] Murray, C.J. and Lopez, A.D. (1997) Global Mortality, Disability, and the Contribution of Risk Factors: Global Burden of Disease Study. The Lancet, 349, 1436-1442. http://dx.doi.org/10.1016/S0140-6736(96)07495-8 